\title{
Correlation of Parenting and Nutrient Intake with Stunting in Children 24-59 Months
}

\author{
Nelly SD Situmeang ${ }^{1}$, Etti Sudaryati ${ }^{2}$ Jumirah $^{2}$ \\ ${ }^{1}$ Master Student in Faculty of Public Health, Universitas Sumatera Utara, Medan, Indonesia \\ ${ }^{2}$ Lecturer in Faculty of Public Health, Universitas Sumatera Utara, Medan, Indonesia \\ Email: else.dea@gmail.com
}

\begin{abstract}
:
Stunting is a chronic nutritional problem due to insufficient intake for a long time, in Indonesia the prevalence is high. The World Health Organization (WHO) classifies if the length/height $z$ score is below -2 SD. The purpose of this study was to analyze the correlation between parenting, and nutrient intake (energy and protein) with stunting in children aged 24-59 years. This study used a cross sectional design with a sample of 117 children. Data collection was carried out with questionnaire instruments for parenting, and 24-hour food recall for nutritional intake. Data stunting was performed by comparing the height of the children measured by the WHO growth standards. Correlation analysis using Pearson correlation analysis. The results showed that the prevalence of stunting for children aged 24-59 months was 50.4\%. There was a significant correlation between parenting with stunting $(r=0.287$ and $p=0.02)$, energy intake with stunting $(r=0.215$ and $p=0.020)$ and protein intake with stunting $(r=0.354$ and $p=0.0001)$. It is recommended that the Ministry of Health improve nutrition surveillance programs, and encourage the community to monitor the growth of children under five years every month in health services.

Keywords:

parenting; intake; energy; protein; stunting
\end{abstract}

\section{Introduction}

In the early of 1000 days, the beginning of life is the critical period of time for growing and developing in children. We called this period of time as golden period (United Nations Children's Fund, 2013). At this golden period the fastest growth happened at ages 3-24 months and after at ages 24-59 months the growth become slower but it's continuous and will be affected to motoric abilities, social, emotional, and cognitive development (Aguayo, 2016).

The main factor of growth and development process are parenting and nutrient intake (Cameron, 2012) Malnutrition problem in the long period of time, lack of energy, protein, micro nutrition could affected to linear growth (stunting) (Beal, 2018). It is similar to research that held in poorest region in Asia that shown us the stunting causes by inefficient of nutrition and infectious. The other factor are age of children, gender, amount of families consumption, income, profession, etc (Dewey, 2016).

If we not handling this malnutrition problems, we could face the lost generation in the future (Owino, 2016). Some of survey that held in Indonesia showing us the prevalence of children with stunting still happened each year about 30-40 percent. According to Riskesdes (Region Health Research) in 2017 prevalence of children with stunting in National is about 30.8\% (Kemenkes, 2018a), decreased from 37\% in 2013 (Kemenkes 2017). The decreasing of prevalence of children with stunting in National are different in Humbang Hasundutan Regency (Kemenkes, 2018b). 
The geographical of Humbang Hasundutan Regency is in North Sumatera Province. From the survey of nutrition assessment status, the prevalence of children with stunting in 2016 about 37\% and increasing to 41.5\% in 2017(Dinkes, 2017). Based on preliminary survey that took from social demographical, the farmer is the most profession followed by trader. This profession also involved women to increase family income. Time of working is about 810 hours/day. Humbang Hasundutan Regency is surplus from agriculture sector such as; rice, vegetables, fruits, carrot, tomato (BPS, 2018). Based on those data the author interested to find out the parenting and nutrient intake, with stunting in children at ages $24-59$ months in Humbang Hasundutan Regency.

\section{Research Method}

This research was conducted descriptively with approach of cross section method on June-August 2018. The population of research are 13.705 children at ages 24-59 months from 10 district. The sampling process was done by selected the district based on amount of its population. The total sample was 117 mother of children at ages 24-59 months that distributed in 3 district who have fulfilled SKDN data, inclusion and exclusion criteria.

The collected data consist of children with stunting at ages 24-59 months, and parenting by interviewing with using questionnaires, nutrient intake to find out the energy adequate and protein adequate by using form food recall 24 hour. The measurements was to find out about height by using microtoise. For the conclusions (stunting or not stunting) is refer to antropometric standardization and nutrition assessment status by Kepmenkes RI Nomor: 1995/Menkes/SK/XII/2010. The collected data were analyzed by SPSS-15 and the relationship analyzed by using Pearson's correlation analyzed.

\section{Result and Discussion}

\subsection{Stunting}

Based on 1st table, about 38\% of children distributed at ages $37-48$ months, and more than a half $(62 \%)$ of children are female. And from 117 children about $(50.4 \%)$ are stunting. If we compare to nutrition assessment status (PSG) in 2017, about (41.5\%) are stunting, but in this research about $(50.4 \%)$ are stunting, and we have large deviation value. But if we see from ages categories (PSG in 2017), the prevalence of children with stunting were higher at ages 0 59 months about (41.5\%), compare to children at ages $0-23$ months about $(23.7 \%)$.

Table 1. Frequency Distribution of Children with Stunting

\begin{tabular}{|c|c|c|}
\hline Children's Characteristic & F & $\%$ \\
\hline Age of Cildren & & \\
\hline $24-36$ months & 42 & 35.9 \\
\hline $37-48$ months & 45 & 38.5 \\
\hline $49-59$ months & 30 & 25.6 \\
\hline Gender & & \\
\hline Male & 55 & 47.0 \\
\hline Female & 62 & 53.0 \\
\hline Stunting & & \\
\hline Normal & 58 & 49.6 \\
\hline Stunting & 59 & 50.4 \\
\hline Total & 117 & 100 \\
\hline
\end{tabular}




\subsection{Parenting}

Based on 2nd table, majority of the respondent's (mother of children) age distributed to $\geq 30$ years is about $51.3 \%$, indicate that they are in productive ages. More than a half of them (76.9\%) were senior high school level, and about $(76.1 \%)$ is a working mother. As a farmer and a trader, more than a half of them (57.3\%) come from a big families that member of a family's $\geq 4$ person.

If we see from the characteristic of the families, the function of the families is to give a parenting influenced by environmental, culture, economic, and value of social that have contributed to growth and development of children. A working women and profession of children's mother will affected to parenting. [7][20]

Table 2. Frequency Distribution of Respondents Based on Characteristic Parenting

\begin{tabular}{|c|c|c|}
\hline Characteristic & $F$ & $\%$ \\
\hline Age of Mother & & \\
\hline$<30$ Years & 57 & 48.7 \\
\hline$\geq 30$ Years & 60 & 51.3 \\
\hline Education of Mother & & \\
\hline SLTP (Junior) & 9 & 7.7 \\
\hline SMA ('Senior) & 90 & 76.9 \\
\hline Academic, University & 18 & 15.4 \\
\hline Profession of Mother & & \\
\hline Working & 89 & 76.1 \\
\hline Not Working & 28 & 23.9 \\
\hline Number of Families & & \\
\hline$>4$ person & 50 & 42.7 \\
\hline$<4$ person & 67 & 57.3 \\
\hline Parenting & & \\
\hline Adequate & 46 & 39.1 \\
\hline Inadequate & 71 & 60.7 \\
\hline Total & 117 & 100 \\
\hline
\end{tabular}

\subsection{Nutrient Intake}

Based on 3rd table, describe about nutrient intake. About $51.3 \%$ count as inadequate energy, and about $56.4 \%$ count as adequate protein.

Table 3.Variable Distribution of Nutrition Intake with Stunting

\begin{tabular}{c|cc}
\hline Variable & $F$ & $\%$ \\
\hline Intake Energy & & \\
Adequate & 67 & 48.7 \\
Inadequate & 50 & 51.3 \\
Intake Protein & & \\
Adequate & 66 & 56.4 \\
Inadequate & 51 & 43.6 \\
\hline & $70.0 \%$ & $13.0 \%$ \\
\hline
\end{tabular}

\subsection{Correlation of Parenting and Nutrient Intake with Stunting}

Based on 4th table can be seen that there is a strong significant correlation between parenting, protein intake $(P<0.01)$ and a significant correlation on energy intake $(p<0.05)$ with stunting in children at ages 24-59 months in Humbang Hasundutan Regency.

Mother has an important contribution to keep the growth and nutrition feeding by a good parenting. The result of research are about (51.3\%) mother's ages $\geq 30$ years, and about $76.1 \%$ are working. A working women and profession of children's mother will affected to parenting. 
Parenting has a significant correlation with stunting in children. Stunting is the description about the indicator of malnutrition chronic, but parenting is behavior of family (mother, father, grandmother, or the other) in the household should lead to keep food adequacy for growth and development children (Ole, 2016).

Inadequate parenting, including lack of mother's knowledge about health and nutrition can affect to resistance and development of immune system to food and drink are weak (Kemenkes, 2018). Parenting practice for children in Indonesia mostly doing by mother. Mother who has good parenting practice will has a children with a good nutrition status (Kemenkes, 2018) .

Parenting is indirect factor to stunting but could affect to quality and quantity of nutrition feeding for children to achieve growth and development optimally (Beal, 2018). Energy source from macro nutrition (protein, fat dan carbohydrate) to support growth and physical activity. Children need energy to build their new body tissue that affect to special dynamic, basal metabolism, physical activity (Supariasa, 2001).

Energy consumption that source from incomplete nutrition is not enough for our body and causes problem to our growth (Supriadi, 2014). Adequate of energy could achieved if energy in equal to energy out, this condition give us an ideal composition. Lack of energy happen if our food consumption not enough, and the body will unbalance with negatif energy, that affect to growth process, decreasing of body weight, short, damage to body tissue (Rosmaina, 2018).

Nutrition is key to children's survival, growth and development. Well-nourished children are healthier, they grow and develop to their full potential and they perform better when they become an adult (Siagian, 2010). Protein is a macro nutrition that main function for growth, cure the cells in our body tissue. Lack of protein causes problem to our growth. Muscle become reduced and weak, and affected to size and body mass. This malnutrition called KEP and stunting (Almatsier, 2009).

Aguayo, 2016 told that protein couldn't substituted with other nutrition as a main factor for growth and development to children. Lack of protein in the long time causes problem to children's growth, children will be shorter and very short. According to research from WHO (2018), a lot of short children find in the same condition that lack of protein too. This thing happen because the protein transform into energy fast enough. So the protein as a main function for growth can't be done

Table 4.Correlation parenting and nutrient intake with Stunting

\begin{tabular}{|l|l|c|}
\hline \multicolumn{1}{|c|}{ Variable } & \multicolumn{1}{c|}{ Pearson Corelasi } & Sig $(2$-tailed $)$ \\
\hline Parenting & $0.287^{* *}$ & 0.002 \\
\hline Energy Intake & $0.215^{*}$ & 0.020 \\
\hline Protein Intake & $0.354^{* *}$ & 0.0001 \\
\hline
\end{tabular}

${ }^{*}$ Correlation is significant at the value $\mathrm{p}<0.05$

**Correlation is significant at the value $\mathrm{p}<0.01$ 


\section{Conclusion}

1. The prevalence of stunting in children at ages $24-59$ months about $(50.4 \%)$.

2. Frequency distribution of respondents based on characteristic parenting : (mother of children) age distributed to $\geq 30$ years is about $51.3 \%$, indicate that they are in productive ages. More than a half of them $(76.9 \%)$ were senior high school level, and about $(76.1 \%)$ is a working mother. As a farmer and a trader, more than a half of them $(57.3 \%)$ come from a big families that member of a families $\geq 4$ person.

3. There is a strong significant correlation between parenting, protein intake $(p<0.01)$ and a significant correlation on energy intake $(\mathrm{p}<0.05)$ with stunting.

\section{Suggestion}

1. The Government of Humbang Hasundutan Regency need to have a policies to decreasing the prevalence of stunting. And involving intersectoral such as (agriculture, fisheries, food sector, PKK, society organization), to give an education especially to the families who have children.

2. Strengthening the program by posyandu to observe the children's growth, health education and health services. The society especially the children's families should concern about a good rearing and eating pattern during the children in a growth period.

3. It is recommended that the Ministry of health improve nutrition surveillance programs, and encourage the community to monitor the growth of children under five years every month in health services.

\section{References}

Almatsier, S. (2009) Prinsip dasar Ilmu Gizi. Jakarta: Gramedia Pustaka.

Aguayo, V. M., \& Menon, P. (2016). Stop stunting: Improving child feeding, women's nutrition and household sanitation in South Asia. Maternal \& Child Nutrition, 12, 311.

Beal, T., Tumilowicz, A., Sutrisna, A., Izwardy, D., \& Neufeld, L. M. (2018). A review of child stunting determinants in Indonesia. Maternal \& Child Nutrition, 14(4), e12617.

Cameron, N. (2012). The human growth curve, canalization and catch-up growth. In Human growth and development (pp. 1-22). Academic Press.

Checkley, W., Epstein, L. D., Gilman, R. H., Cabrera, L., \& Black, R. E. (2015). Effects of acute diarrhea on linear growth in Peruvian children. American Journal of Epidemiology, 157(2), 166-175.

De Onis, M. and Branca, F. (2016). Childhood stunting: a global perspective. Maternal \& child nutrition, 12, pp.12-26.

Dewey, K. G., \& Begum, K. (2010). Why stunting matters. Jurnal Gizi Klinik Indonesia. Diakses dari https://jurnal.ugm.ac.id/jgki/article/view/22682.

Dinas Kesehatan Provinsi Sumatera Utara (2017). Buku Saku Pemantauan Status Gizi Tahun 201, Medan : Dinkes Prov.Sumatera Utara.

Hasundutan, B. P. S. K. H. (2018). Humbang Hasundutan dalam Angka 2018. Dolok Sanggul: BPS Kab. Humbang Hasundutan.

Keputusan Menteri Kesehatan Republik Indonesia Nomor 1995 Tahun 2010 Tentang Standar Antropometri Penilaian Status Gizi Anak.

Kementerian Kesehatan, RI. (2017). Pemantauan status gizi (PSG). Jakarta: Kementerian Kesehatan R. I.

Kementerian Kesehatan, RI. (2018a). Riset Kesehatan Dasar (Riskesdas) Tahun 2018. Diakses 
dari https://www.depkes.go.id/download/riskesda2018.

Kemenkes, RI. (2018b), Penurunan Stunting jadi Fokus Pemerintah. Diakses dari http://www.depkes.go.id.

Kemenkes, RI. (2018c), Cegah Stunting dengan Perbaikan Pola Makan, Pola Asuh, dan Sanitasi. Diakses dari http:/ /www.depkes.go.id.artikel/cegah stunting.

Ole Tankoi, E.O., Asito, S.A, Adoka, S. (2016) Determinants of Malnutrition among Children Aged 6-59 Months in Trans-Mara East Sub-County, Narok County, Kenya. Int J Pub Health Safe 1: 116.

Owino, V., Ahmed, T., Freemark, M., Kelly, P., Loy, A., Manary, M., \& Loechl, C. (2016). Environmental enteric dysfunction and growth failure/stunting in global child health. Pediatrics, 138(6).

Rahmayana, A.I., Ibrahim \& Damayati D.S. (2014). Hubungan pola asuh ibu dengan kejadian stunting anak usia 24-59 bulan. Public Health Science Journal, 6(2),13.

Rosmalina, Y., Luciasari, E., Aditianti, A., \& Ernawati, F. (2018). Upaya pencegahan dan penanggulangan batita stunting: systematic review. Gizi Indonesia, 41(1), 1-14.

Supariasa, I. D. N., Bakri, B., \& Fajar, I. (2016). Penilaian Status Gizi (Edisi ke- 2). Jakarta: EGC.

Sugiyono. (2016). Metodologi penelitian kombinasi. Bandung: CV. Alfabeta.

Sugiono, P. dr. (2013). Statistika untuk penelitian. Badung: CV. Alfabeta

Siagian, A. (2010). Gizi, imunitas, dan penyakit infeksi. Jakarta: Erlangga.

Sjarif, D. R., Lestari, E. D., Mexitalia, M., \& Nasar, S. S. (2014). Buku ajar nutrisi pediatrik dan penyakit metabolik (Jilid III). Jakarta: Ikatan Dokter Anak Indonesia

United Nations Children's Fund. (2013). Improving Child Nutrition: The Achievable Imperative for Global Progress. https://www.unicef.org/gambia/improving child nutrition_the achievable imperative for global_progress.pdf.

Pratiwi, T. D., Masrul, M., \& Yerizel, E. (2016). Hubungan pola asuh ibu dengan status gizi balita di Wilayah Kerja Puskesmas Belimbing Kota Padang. Jurnal Kesehatan Andalas, $5(3)$.

WHO. ( 2016). Maternal, infant and young child nutrition :Guidance on ending the inappropriate promotion of foods for infants and young children.Provisional agenda item

WHO. (2018). Reducing Stunting in Children: Equity Considerations for Achieving The Global Nutrition Targets 2025. Diakses dari https://apps.who.int/iris/handle/10665/260202 